\title{
A Response Analysis of Mobile Augmented Reality Application for Tourism Objects
}

\author{
Imam Tahyudin ${ }^{1}$, Dhanar Intan Surya Saputra ${ }^{2}$ \\ ${ }^{1}$ Departement of Information System, STMIK AMIKOM Purwokerto, Indonesia \\ ${ }^{2}$ Departement of Informatic Engineering, STMIK AMIKOM Purwokerto, Indonesia
}

\begin{tabular}{ll} 
Article Info & ABSTRACT \\
\cline { 3 - 3 } Article history: & $\begin{array}{l}\text { As a form of innovation in a promotion media Tourism Objects in Indonesia } \\
\text { especially at Purbalingga District, one is through Mobile Augmented Reality } \\
\text { (MAR). The utilization of technology application of MAR, give the }\end{array}$ \\
$\begin{array}{l}\text { Received Oct 22, } 2016 \\
\text { Revised Jun 23, 2017 }\end{array}$ & $\begin{array}{l}\text { impression of interactive and real towards an object tourism and provide a } \\
\text { special experience for tourists to get the information completely including } \\
\text { the tourism location. To deliver care facilities to users, we need the } \\
\text { evaluation to development or improvement for next application. The method } \\
\text { Keyword: }\end{array}$ \\
$\begin{array}{l}\text { used in this research is evaluation of user satisfaction towards the multimedia } \\
\text { elements. The result of MAR user satisfaction showed that almost all } \\
\text { respondents are well satisfied. }\end{array}$
\end{tabular}

Copyright $@ 2017$ Institute of Advanced Engineering and Science. All rights reserved.

\section{Corresponding Author:}

Imam Tahyudin,

Departement of Information System,

STMIK AMIKOM Purwokerto,

Jl. Letjendpol Soemarto, Purwokerto, Central Java, Indonesia.

Email: imam.tahyudin@amikompurwokerto.ac.id

\section{INTRODUCTION}

Tourism development is a form of work program seriously done by every tourist object management including Purbalingga district. The development of this potential will influence significantly to improving the economy of rural communities, with the potential of the uniqueness of a tourist village will become a potential tourist attraction. Tourism potential tackled seriously, directed, and professional impact on the increase of local revenue. Therefore, tourism can be a mover (prime mover) the development of other sectors that can affect regional economic growth [1].

Increased innovation and creativity of a product is an obligation, as a form of innovation in media promotional tour in Purbalingga through the application of technology. One attempt to join in and do the promotion of tourism in Purbalingga through creative ideas with the technology utilization of Mobile Augmented Reality (MAR).

The Purbalingga travel brochure development has used the technology applications of Mobile Augmented Reality (MAR) which giving the impression of a real interactive and the attraction and provide a special experience for visitors to get complete information through brochures with each served content such as video and photo gallery [2]. Furthermore, this application also used Location Based Service (LBS) on Android smartphones which can help and facilitate the tourists or the public in obtaining information about tourist sites and can save time for searching the information [3].

The AR is getting more important now days as it can be used in many fields and encouraged by the new smartphones and tablets revolution. Implementation of applications using augmented reality technology is extremely diverse, from applications such as single-user, multi-user, based desktop and through mobile web. In addition, the topics and the content of any variety such as games, tourism to smart-city. The 
advantages of the application of augmented reality that provides entertainment, positive interaction, challenges and specific experience gained by users [4]. Technology augmented reality (AR) allow public access via smartphone and tablet mobile devices. Mobile augmented reality technology provides great potential to everyday life around the community. Through the use of MAR, users can create up to download content such as location information restorant, apartments and physical conditions in the environment around them [5].

Moreover, several studies in the implementation of AR have been carried out, such as Kourouthanassis, et.al, have presented that mobile augmented reality (MAR) travel guide, named CorfuAR for supporting mobile tourism applications at the principal city of Corfu island in Greece. The research showed that behavioral intention to use the system was positively affected through feeling of pleasure and excitement. Huang, et al, also has implemented a mobile Augmented Reality (AR) to capture images of the book. The captured of images are stored into the cloud, then the image features are checked. If the images are matching, then it will be sent to the Android smartphone platform. Meanwhile, the Chunghwa Telecoms Hicloud as a cloud was used [6],[7]. Saputro et al. using the AR able to realize the virtual world to the real world which can present the objects of the image in the book becomes a 3D object, so that the reader to be motivated to find out more [8]. Saputra et al. also study the implementation of AR in a daily news company. That it can be done through technology innovation Mobile Augmented Reality which is shown to the reader to better appeal to customers and provide information not only text and images but also video content [9]. The other research designs and implements an AR for smart phone which combine the G.P.S location-based technology and virtual trace technology to provide information to users on a designated building or buildings nearby [10].

Application of MAR on travel brochures Purbalingga it has been applied previously, showed a positive trend in its use. While the development of the application with the additional features of location based services (LBS) indicate user interest in interacting on the application, and of course provides convenience in searching for and finding the nearest tourist sites. In order to provide convenience to the user services, hence the need for an evaluation to determine how much public response in this case the user rating of applications, as well as to provide an assessment to the development or improvement of subsequent applications. One method used to measure the evaluation in this study is Evaluation of User Satisfaction Towards the Multimedia Elements.

User satisfaction with an information system can be defined as the overall affective evaluation of an end-user regarding their experiences in relation to the information system. Motivational elements including typographical cueing, color, graphical images, animation and sound in the interactive multimedia software can motivate the user and increase satisfaction but follow the principles of motivational design elements. Users with different characteristics have different perception on the multimedia application [11]. User satisfaction is one component of human interaction with computers. Satisfaction is defined as the act of giving what is needed or desirable [12],[13]. In every interaction between users and interfaces, achieving user satisfaction is key in determining the success of a product or system [14]. Factors that affect users are satisfied is unique to each other depending on individual needs, expectations and no experience when interacting with the interface [15]. Therefore, an important measure of the effectiveness of a multimedia application is the user experience captured in terms of enjoyment or satisfaction and information assimilation [16],[17].

This evaluation is done after the application of MAR applications in travel brochures as well as the development of LBS-based MAR. User satisfaction evaluation is necessary to determine the level of satisfaction and the appropriateness of using the element in multimedia applications. The use of multimedia elements as a model in the evaluation process is done through quisoner by asking questions covering four multimedia components, namely text, interactivity, animation and graphical image [17].

This study is organized as follows: Section 2 discuss the methodology used in this research; Section 3 presents result and discussion that we show the result of testing and evaluation of MAR user satisfaction; finally, we conclude this research in section 4.

\section{RESEARCH METHOD}

Explaining This study focus to evaluate performance by using the Evaluation model of User Satisfaction Towards the Multimedia Elements. Multimedia has been proven as one of the tools to communicate and visualize ideas, knowledge and concepts in a simple way. Multimedia is defined as the combination of various digital media types, such as text, images, sound, and video, into an integrated multisensory interactive application or presentation to convey a message or information to an audience [18]. Evaluation of user satisfaction was done with a questionnaire for the assessment of four multimedia elements, 
namely text, interactivity, animation, and a graphical image [17]. The framework for this research is divided into three stages as shown in Figure 1.

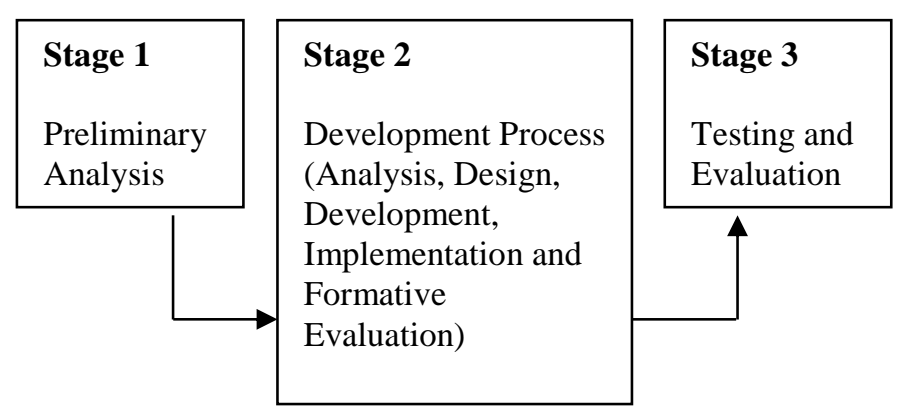

Figure 1. Research Framework

Stage 1 is a preliminary analysis based on interviews with tourists to get comments about how the media is supporting the promotion of tourism in Purbalingga that exist today. The process has been carried out in this stage. Stage 2 is a development process that involves five steps MAR based on the model ADDIE: Analysis, Design, Development, Implementation and Formative Evaluation. Data collected from the analysis used to design and develop applications. Stage 3 is the testing and evaluation. This paper will discuss the results of the evaluation in terms of user satisfaction of the multimedia elements designed specifically in MAR applications.

\section{RESULTS AND DISCUSSION}

\subsection{Data Collection}

Tests on user acceptance (beta test) conducted by questionnaire, once they finish testing the application. Table 1 contains the questionnaire data used for beta testing.

Table 1. Questionnaire of Beta Test for Teacher

\begin{tabular}{clll}
\hline \multirow{2}{*}{ No. } & \multicolumn{1}{c}{ Aspect } & \multicolumn{2}{c}{ Rating } \\
\cline { 2 - 4 } 1. & $\begin{array}{l}\text { Display of application MAR is } \\
\text { actractive and interactive }\end{array}$ & & \\
2. & $\begin{array}{l}\text { Text on the application is clear and easy } \\
\text { to understand }\end{array}$ & & \\
3. & Application is already appropriate to use & & \\
4. & $\begin{array}{l}\text { The content on the application are in } \\
\text { accordance with the tourism objects }\end{array}$ & \\
\hline
\end{tabular}

Based on the Table 1, rating of strongly agree is 4 ; agree is 3 , disagree is 2 ; and strongly disagree is 1. Furthermore, the questionnaire data is processed using a Likert measurement [19].

\subsection{Mobile Augmented Reality for Tourism Objects}

The applications will be constructed through several stages. The first stage is to design the layout of the promotional brochure. The second stage is the determination of the image to be used as a marker application. The last stage is to upload the content to be displayed on the marker as AR information (tourism objects). At this stage of development, implementation MAR content supplied additional services such as location based services (LBS). The general system architecture can be seen in Figure 2 below: 


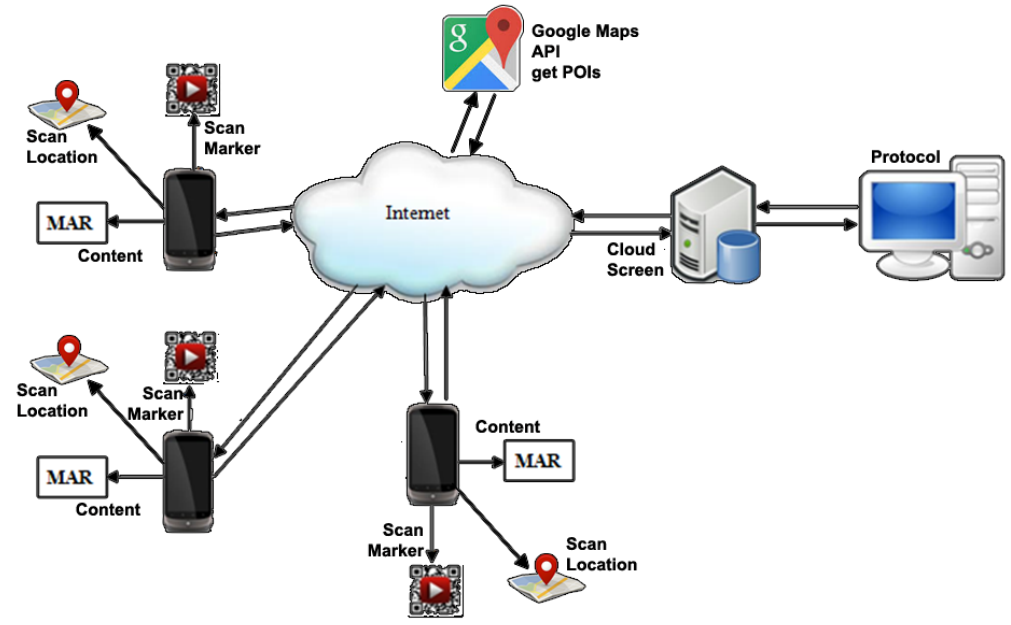

Figure 2. Research Framework [3]

The interface of app for Android platform is used to perform image or marker detection in the brochure then display the information of AR content includes video, images, animation, virtual buttons and location based that contain a particular link, Figure 3.
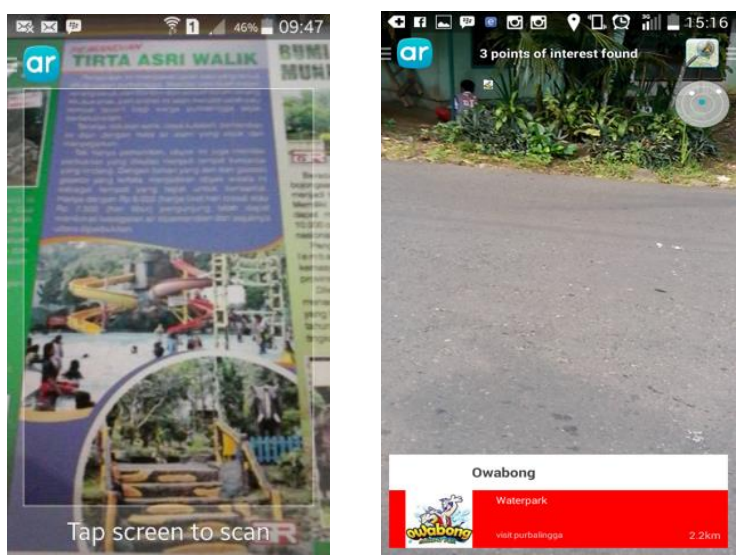

Figure 3. MAR Application

\subsection{Results of Testing and Evaluation of User Satisfaction against Multimedia Element}

Testing and evaluation of user satisfaction on the use of multimedia elements in the MAR applications were made by 20 tourists as respondents. It is based on statistical data of visitors or application of successful MAR documented in the system (Figure 4). Table 2 until Table 5 show the results of the questionnaire data processing using SPSS Statistics software to calculate the mean for each multimedia element. 


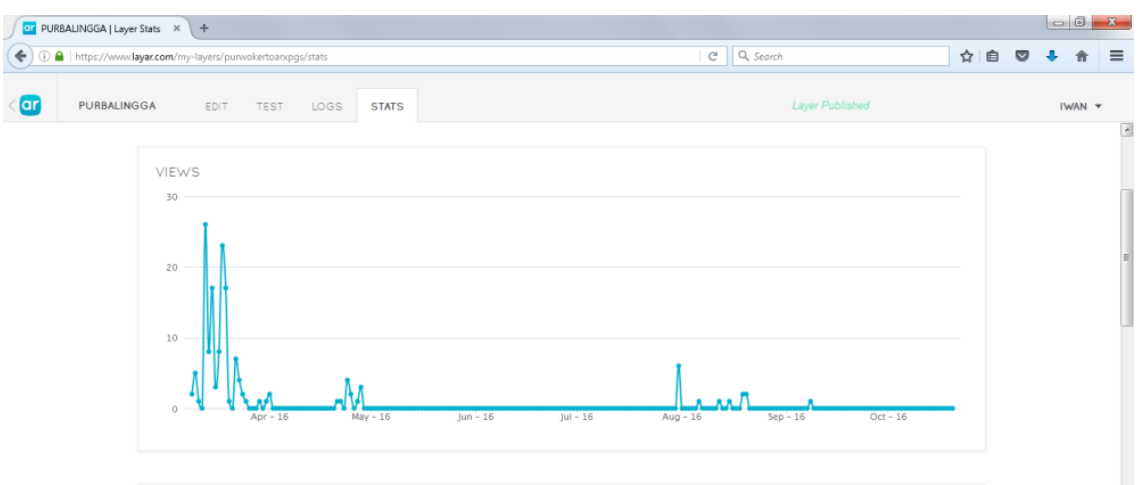

Figure 4. Statistics Views

Table 2. Mean score for element of text used in application

\begin{tabular}{clc}
\hline No. & \multicolumn{1}{c}{ Aspect } & Mean \\
\hline 1. & Easy to read texts & 3.53 \\
2. & Fonts are suitable & 3.33 \\
3. & Clear text layout & 3.70 \\
4. & Information positions are standardized & 3.51 \\
5. & Easy to understand the text explanation & 3.40 \\
\hline
\end{tabular}

Based on the results of testing against the elements text in Table 2, it can be concluded that respondents almost agreed with the writing of the text (question 1), typeface (question 2), the text layout (question 3), position of the text of the application (question 4), and were able to understand clarification of the text given (question 5). This is evidenced by the mean value greater than 3.00 of the maximum value of 4 for all aspects of assessment. It means that the respon for text used in application is good.

Table 3. Mean Score for element of graphical image used in application

\begin{tabular}{clc}
\hline No. & \multicolumn{1}{c}{ Aspect } & Mean \\
\hline 1. & Colors used are attractive & 3.25 \\
2. & Graphics are clear & 3.55 \\
3. & Graphics used are suitable & 3.56 \\
4. & Explanation using graphics are easy to understand & 3.50 \\
\hline
\end{tabular}

Table 3 explains about the result of respon for the elements graphical image in application. According to this table can be seen in question 1 that respondens almost agreed with the use of color. And then in question 2 and 3 respondens are approximately strong agree that graphics are clear and suitable. In addition, the respon of application that easy to understand to graphics and annotations in question 4 is also almost strong agree.

Table 4. Mean score for element of animation used in application

\begin{tabular}{clc}
\hline No. & \multicolumn{1}{c}{ Aspect } & Mean \\
\hline 1. & The animations used in the explanation are helpful to understand & 3.55 \\
2. & The objects & 3.27 \\
3. & The animations elements used are suitable to explain the objects & 3.33 \\
4. & The animations are attractive & 3.78 \\
\hline
\end{tabular}

According to Table 4 shows the results of respon to animation used. Generally, the result seen that the responden agree about this evaluation. It can be seen in question 1 to 3 that respondens almost agree with the use of animation to understand the tourism objects, animations are used in accordance with the objects, the animation used is interesting. Moreover, in question 4 the result is the responden almost strongly agree that animation is able to visualize the tourism objects as well which the mean value is 3.78 . 
Table 5. Mean score for element of interactivity used in application

\begin{tabular}{clc}
\hline No. & \multicolumn{1}{c}{ Aspect } & Mean \\
\hline 1. & Interactivity tools are easy to use & 3.48 \\
2. & Navigations are easy & 3.78 \\
3. & The links used are correct & 3.67 \\
4. & Buttons used are standardized & 3.73 \\
\hline
\end{tabular}

The results of respon of interactivity is presented in Table 5. In general the results are almost extremely agree. In question 1 that respondents agreed with the way users interact with the application. Next, the users can navigate the application with easy (Question 2), they can use link (Question 3) and they can use buttons complies with the standards (Question 4) are almost strongly agree.

The results of the evaluation of user satisfaction to each multimedia element, indicates that the text element has an average value of the highest, while the element of interactivity has the lowest average value compared with the average value of the other multimedia elements. Figure 5 shows a graph of the average value of each multimedia element in the MAR for Tourism Objects at Purbalingga district.

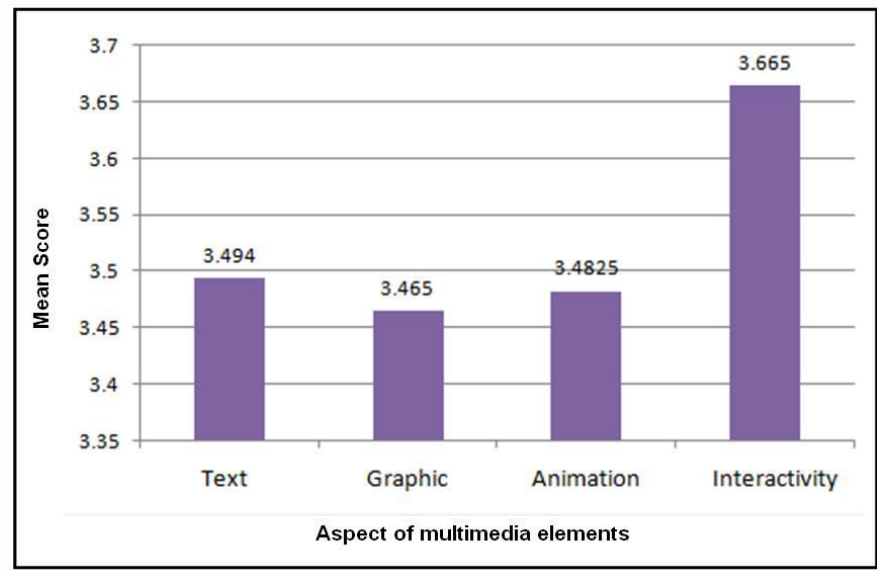

Figure 5. Overall mean score for multimedia elements in application

Based on Figure 5, the highest mean score is Interactivity which is around 3.6. After that text and animation elements which are approximately by 3.49 and 3.48 respectively. The lowest mean score of multimedia elements is graphic (3.46). Hence, according to this result the graphic element needs to be improved in the MAR application of tourist object in Purbalingga district.

\section{CONCLUSION}

The results of user satisfaction evaluation of the four elements of multimedia showed that use of text in the application has a mean value of 3.494 , the graphic has a mean value of 3.465 , animation has a mean value of 3.4825, and interactivity has a mean value of 3.665. Based on the test results, it can be concluded that the respondents are generally satisfied with the use of multimedia elements on the MAR application of Purbalingga tourist object. For future work, it is interesting if the MAR application combine with game based on augmented reality.

\section{ACKNOWLEDGEMENTS}

This research supported by various parties. We would like to thank for funding from Ministry of Research and Technology and Directorate of Higher Education (KEMENRISTEKDIKTI) and also STMIK AMIKOM Purwokerto, Indonesia. In addition, we thank for anonymous reviewers who gave input and correction for improving this research. 


\section{REFERENCES}

[1] Anonim, "Tourism Destination Development in Purbalingga," 2015.

[2] Tahyudin I., et al., "An Interactive Mobile Augmented Reality for Tourism Objects at Purbalingga District," TELKOMNIKA Indonesian Journal of Electrical Engineering, vol/issue: 16(3), pp. 559-564, 2015.

[3] Tahyudin I. and Saputra D. I. S., "Implementation of a Mobile Augmented Reality Application with Location Based Service for Exploring Tourism Objects," International Conference on Big Data and Advanced Wireless Technologies BDAW, Paris, France, 2016.

[4] A. G. Crespo, et al., "CESARSC: Framework for creating Cultural Entertainment Systems with Augmented Reality in Smart Cities," Computer Science and Information Systems, vol/issue: 13(2), pp, 395-425, 2016.

[5] T. Liao and L. Humphreys, "Places: Using Mobile Augmented Reality To Tactically Reengage, Reproduce, and Reappropriate Public Space," New Media and Society, pp. 1-18, 2014.

[6] P. Kourouthanassis, et al., "Tourists responses to mobile augmented reality travel guides: The role of emotions on adoption behavior," Pervasive and Mobile Computing, vol. 18, pp. 71-87, 2015.

[7] B. R. Huang, et al., "Mobile Augmented Reality Based on Cloud Computing," International Conference on Anticounterfeiting, Security, and Identification, 2012.

[8] Saputro R. E. and Saputra D. I. S., "The development of Learning Media for Introducing the Organ Human Digestion Using Augmented Reality,” Buana Informatika Journal, vol/issue: 6(2), pp. 153-162, 2015.

[9] Saputra D. I. S., et al., "Implementation of Mobile Augmented Reality based on Cloud Computing at Daily News Radar Banyumas," Proceeding of Informatics National Seminar, UPN Veteran Yogyakarta, vol/issue: 1(2), pp. B14-B21, 2013.

[10] C. O. Chung, et al., "Augmented Reality Navigation System on Android," Int. J. Electr. Comput. Eng., vol/issue: 6(1), pp. 406, 2016.

[11] L. Xiao and S. Dasgupta, "Measurement of User Satisfaction with Web-Base Information Systems: An Empirical Study," Eighth Americas Conference on Information Systems, 2002.

[12] Z. Zahidi, et al., "User Satisfaction Determinants for Digital Culture Heritage Online Collections," International Journal of Advanced Computer Science and Applications, 2014.

[13] Merriam-Webster.com. 2014. http://www.merriam-webster.com/dictionary/satisfaction.

[14] A. Ali, et al., "Measuring user satisfaction from e-government services: Lessons from Jordan," Government Information Quarterly, vol/issue: 30(3), pp. 277-288, 2013.

[15] Z. Zahidi, et al., "Understanding the User Experience (UX) Factors that Influence User Satisfaction in Digital Culture Heritage Online Collections for Non-Expert Users," Science and Information (SAI) Conference, London, pp. 27-29, 2014.

[16] W. W. Chin and M. K. Lee, “A Proposed Model and Measurement Instrument for the Formation of IS Satisfaction: The Case of End-User Computing Satisfaction," Proceedings of the Twenty-First International Conference on Information Systems, 2000.

[17] L. B. Y. Khedif, et al., "The Evaluation of Users' Satisfaction towards the Multimedia Elements in a Courseware," in Procedia-Social and Behavioral Sciences, vol. 123, pp. 249-255, 2014.

[18] M. Neo and K. Neo, "Innovative teaching: Using Multimedia in a Problem-Based Learning Environment," Educational Technology and Society Education, vol/issue: 4(4), 2001.

[19] R. Likert, "A technique for the measurement of attitudes," Archives of Psychology, vol/issue: 22(140), pp. 5-55, 1932.

\section{BIOGRAPHIES OF AUTHORS}

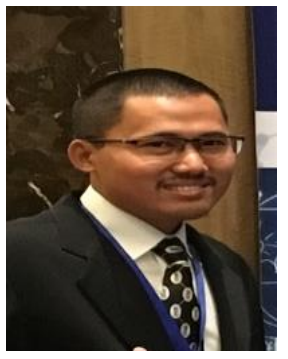

Imam Tahyudin was born in Indramayu, West Java, Indonesia. He graduated from Jenderal Soedirman University, Purwokerto in 2006 in the field of Mathematics, and he completed a Master at Jenderal Soedirman University in 2010 in the field of Management and then, he graduated a master degree at STMIK AMIKOM Yogyakarta in 2013 in field of Information Technology. Currently, he is a Ph. D student of Computer Science in Kanazawa University, Japan. He was a Lecturer in STMIK AMIKOM Purwokerto, Central Java, Indonesia since 2009. $\mathrm{He}$ is a member of the International Society of Management Science and Engineering Management (ISMSEM), Institute of Advanced Engineering and Science (IAES), Association of Computing and Informatics Institutions Indonesia (APTIKOM), Indonesian Computer, Electronics, Instrumentation Support Society (IndoCEISS), Association of Information System (AIS) and Association of Information System for Indonesia (AISINDO).

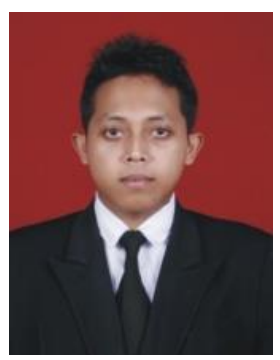

Dhanar Intan Surya Saputra was born in Purbalingga, Central Java, Indonesia. He graduated from STMIK AMIKOM Purwokerto in 2009 in the field of Informatic Engineering, and he completed a Master degree at STMIK AMIKOM Yogyakarta in 2013 in field of Information Technology. He was a Lecturer in STMIK AMIKOM Purwokerto, Central Java, Indonesia since 2010, and he was a Chief Operations Officer (COO) in AMPU Studio Purwokerto. 